\title{
PENGUJIAN 13 JAGUNG MANIS HIBRIDA DI ULTISOL
}

\section{Evaluation of 13 Hybrids Sweet Corn in Ultisol}

\section{Tita Marta Sela ${ }^{1}$, Mohammad Chozin ${ }^{2 *}$, Usman Kris Joko Suharjo ${ }^{2}$ dan Nanik Setyowati ${ }^{2}$}

\author{
${ }^{1}$ Alumni Program Studi Agroekoteknologi, Universitas Bengkulu. \\ ${ }^{2}$ Jurusan Budidaya Pertanian, Fakultas Pertanian, Universitas Bengkulu. \\ *Alamat korespondensi: mchozin@unib.ac.id
}

\begin{abstract}
ABSTRAK
Pemanfaatan tanah ultisol untuk budidaya jagung manis dengan produktivitas tinggi dapat menggunakan bahan tanam yang mampu beradaptasi baik. Penelitian bertujuan untuk membandingkan pertumbuhan dan hasil 13 jagung manis hibrida di tanah ultisol. Penelitian dilaksanakan pada bulan Oktober sampai Desember 2018 di Desa Babatan, Kecamatan Sukaraja, Kabupaten Seluma, Bengkulu dengan ketinggian tempat $15 \mathrm{~m}$ dpl. Rancangan yang digunakan yaitu Rancangan Acak Kelompok Lengkap (RAKL) faktor tunggal. Perlakuan terdiri atas 13 jagung manis hibrida yang merupakan hasil persilangan dialel. Variabel yang diamati yaitu tinggi tanaman, diameter batang, umur muncul bunga jantan, umur muncul bunga betina, tinggi tongkol, panjang tongkol berkelobot, panjang tongkol tanpa kelobot, diameter tongkol berkelobot, diameter tongkol tanpa kelobot, bobot tongkol berkelobot, bobot tongkol tanpa kelobot, jumlah baris biji per tongkol, jumlah biji per baris, bobot tongkol per petak dan total padatan terlarut. Hasil analisis keragaman menunjukkan bahwa penampilan pertumbuhan dan hasil setara dengan Paragon yang digunakan sebagai varietas pembanding. Pengecualian dijumpai pada Caps5x Caps22 yang mempunyai ukuran tongkol berkelobot dan tanpa kelobot lebih panjang dibandingkan Paragon. Pengecualian juga dijumpai pada Caps15xCaps17a yang memiliki jumlah baris pada tongkol lebih banyak dibandingkan varietas Paragon.
\end{abstract}

Kata kunci: hibrida, jagung manis, ultisol.

\section{ABSTRACT}

Utilization of ultisol for growing adaptive sweet corn with high yield can be done. The objective of the experiment was to compare the characters of growth and yield of 13 hybrids sweet corn in ultisol. The study was conducted in October to December 2018 in village of Babatan, Sukaraja subdistrict, Seluma Regency, Bengkulu with a altitude of $15 \mathrm{~m}$ above sea level. The experimental design of a single factor by Complete Randomized Block Design (CRBD) was applied. The material of 13 hybrids sweet corn of which resulted through diallel crossing. Variables observed were plant height, stem diameter, flowering male and female, cob characters of height, ear length and diameter, length without husk, ear diameter without husk, cob ear length, ear cobs without husk, number of rows of seeds per cob, number of seeds per row, weight of cobs per plot and total dissolved solids. The results showed that in general characters of growth and yield equivalent to Paragon as a check variety. Exceptions were found in Caps15xCaps22 which had the longer of cob with or without husk and Caps $15 x$ Caps17a which had more ear seed rows compared to Paragon.

Keywords: hybrids, sweet corn, ultisol

\section{PENDAHULUAN}

Jagung manis (Zea mays Saccharata Sturt) merupakan tanaman hortikultura yang sudah lama dikenal di Indonesia yang berbentuk tongkol dan dibutuhkan dalam keadaan segar. Jagung manis memiliki rasa lebih manis dan umur tanaman lebih singkat dari pada jagung pipil (Dewani, 2004). Jagung manis memiliki potensi sebagai bahan pangan karena kandungan nutrisinya. Kadar gula pada biji jagung manis bervariasi antara 4-12\%, sedangkan kandungan airnya mencapai $74-76 \%$. Tiap $100 \mathrm{~g}$ jagung manis yang dikonsumsi 
mengandung protein $(2,1-4,5 \%)$, pati (3$20 \%)$, lemak (1,1-2,7\%), serat (0,9-1,9\%), vitamin C (9-12 mg), dan unsur-unsur lain seperti vitamin A, B1, B2, serta mineral seperti sodium, kalsium, dan magnesium (Szymanek et al., 2006). Jagung manis umumnya di konsumsi dalam kondisi segar setelah dimasak. Disamping itu, jagung manis dapat dibuat menjadi bermacammacam olahan makanan (Rubatzky dan Yamaguchi, 1997).

Di Indonesia, jagung manis umumunya dibudidayakan di tanah yang subur dan ditanam secara bergiliran dengan jenis tanaman lain (Soegito dan Adie, 1993). Namun, ketersediaan tanah subur semakin terbatas dikarenakan alih fungsi lahan atau bersaing dengan komoditas tanaman lain dalam penggunaan lahan. Oleh karena itu, pengembangan jagung manis perlu diarahkan ke lahan-lahan yang selama ini dipandang suboptimal, termasuk diantaranya adalah lahan Ultisol.

Luas lahan ultisol di Indonesia mencapai kurang lebih 25\% dari seluruh lahan daratan (Subagyo et al., 2004) dan jika dioptimalkan akan memiliki potensi besar untuk pengembangan produksi jagung manis. Tingkat kesuburan yang rendah merupakan permasalahan utama yang membatasi pemanfaatan lahan ultisol. Ultisol sebagai tanah mineral masam dicirikan dengan $\mathrm{pH}$ tanah rendah (3-5), kejenuhan basa rendah, kandungan bahan organik rendah, miskin kandungan hara $\mathrm{P}, \mathrm{Ca}, \mathrm{Mg}, \mathrm{Na}$, dan K. Kadar Al tanah ultisol tinggi, sehingga berpotensi besar terjadi keracunan Al (Prahastuti, 2005).

Terdapat dua pendekatan yang dapat dilakukan agar budidaya hibrida jagung manis pada Ultisol dapat menghasilkan produktivitas tinggi, yaitu perbaikan kondisi tanah dan penggunaan bahan tanam yang beradaptasi baik pada kondisi Ultisol. Perbaikan kondisi tanah yang biasa dilakukan adalah pemberian amelioran dan pemupukan. Namun, pendekatan tersebut dalam jangka panjang menjadi tidak ekonomis (Martani et al., 2000; Dewanto et al., 2013). Pendekatan yang kedua dipandang lebih ekonomis karenatidak banyak memerlukan input produksi yang tinggi, serta memiliki keunggulan yang baik seperti hasil lebih stabil atau konsisten, pertumbuhannya sama, dan memiliki keunikan yang dicirikan warna rambut tongkol bahkan tahan terhadap faktor biotik dan abiotik seperti tahan terhadap kekeringan dan penggerek batang.

Bahan tanaman yang baik diperoleh dengan cara menyilangkan antara galur murni atau inbrida. Jika bahan tanam sudah diperoleh maka harus dilakukan uji daya hasil pendahuluan dan dilanjutkan uji multilokasi. Kriteria bahan tanaman yang baik adalah seragam, produksi tinggi dan memiliki keunggulan seperti sifat 
ketahanan terhadap faktor biotik dan abiotik tertentu.

Selama ini umumnya benih jagung manis yang tersedia berasal dari varietasvarietas yang dikembangkan untuk lahanlahan tanpa atau sedikit memiliki permasalahan kesuburan tanah. Hasil beberapa penelitian menunjukkan jagung manis yang ditanam pada ultisol memiliki penampilan yang lebih rendah dibanding potensi hasilnya (Firnia dan Fatmawaty, 2009). Oleh karena itu, evaluasi penampilan varietas-varietas jagung manis pada ultisol perlu dilakukan sebelum varietas-varietas tersebut diproduksi pada lahan ultisol dalam skala besar.

Peneliti jagung manis dari Fakultas Pertanian Universitas Bengkulu telah berhasil mengambangkan 8 galur inbrida harapan dan melalui persilangan dialel, galur-galur tersebut menghasilkan 28 hibrida (Chozin et al., 2017). Terdapat 13 jagung manis hibrida yang perlu diuji penampilannya pada Ultisol agar dapat diproduksi dengan hasil yang optimal. Penelitian ini bertujuan untuk membandingkan pertumbuhan dan hasil 13 jagung manis hibrida di ultisol.

\section{METODE PENELITIAN}

Penelitian dilaksanakan pada bulan Oktober sampai Desember 2018, di Desa Babatan, Kecamatan Sukaraja, Kabupaten Seluma, Bengkulu pada ketinggian 15 m di atas permukaan laut. Bahan yang digunakan adalah pupuk Urea, $\mathrm{KCl}$, TSP, insektisida berbahan aktif carbofuran dan fipronil 50 $\mathrm{SC}$, serta benih jagung manis (Caps2, Caps3, Caps5, Caps15,Caps17a, Caps17b, Caps22, Caps23, dan Paragon). Paragon merupakan varietas yang dipilih sebagai varietas pembanding, karena Paragon secara umum memiliki hasil tinggi, diameter tongkol besar, dan ukuran biji besar. Alat yang digunakan adalah timbangan, jangka sorong digital, meteran dan hand refractometer.

Rancangan yang digunakan dalam penelitian ini adalah Rancangan Acak Kelompok Lengkap (RAKL) faktor tunggal. Faktor atau perlakuan yang diuji adalah 13 Hbrida jagung manis yang merupakan hasil persilangan dialel. Galurgalur tersebut menghasilkan 28 hibrida (Chozin, et al., 2017). Tiga belas jagung manis hibrida, yaitu: Caps2 x Caps15, Caps3 x Caps5; Caps3 x Caps23, Caps5 x Caps17b, Caps5 x Caps22, Caps15 x Caps22, Caps15 x Caps17a, Caps17b x Caps23, Caps17b x Caps22, Caps17a x Caps22, Caps17a x Caps17b, Caps22 x Caps23 dan Paragon.

\section{Tahapan Penelitian}

1. Analisis Tanah Awal

Analisis tanah awal dilakukan di laboratorium ilmu tanah Universitas Bengkulu untuk mengetahui keasaman tanah (pH), N, P, dan K. Jenis tanah Ultisol 
yang digunakan sudah lama tidak digunakan untuk kegiatan pertanian. Sampel tanah diambil sebanyak 3 titik dari lokasi penelitian untuk dianalisis di Laboratorium Ilmu Tanah, Fakultas Pertanian, Universitas Bengkulu dengan metode komposit. Analisis tanah awal dilakukan sebelum penanaman.

2. Persiapan lahan

Pengolahan lahan dimulai satu minggu sebelum tanam dengan cara membersihkan gulma dan vegetasi lainnya secara manual. Tanah diolah hingga gembur menggunakan cangkul, selanjutnya dibuat petakan dengan ukuran 39 x 6,25 m sebanyak tiga blok dengan jarak antar blok $500 \mathrm{~cm}$. Luasan lahan yang digunakan sebesar $732,25 \mathrm{~m}^{2}$.

Penanaman dilakukan dalam bentuk barisan dengan jarak antar baris $75 \mathrm{~cm}$ dan jarak dalam baris $25 \mathrm{~cm}$. Satu genotipe terdiri dari 4 baris dan 25 tanaman, sehingga populasi tanaman setiap genotipe sebanyak 100 tanaman. Benih ditanam pada kedalaman $3 \mathrm{~cm}$ dan setiap lubang tanam diberi insektisida berbahan aktif carbofuran dengan dosis setara $20 \mathrm{~kg} / \mathrm{ha}$.

Pengairan dilakukan pada sore hari apabila kondisi tanah kering dan tidak turunhujan.Penjarangan dilakukan saat tanaman berumur 1 minggu setelah tanam (mst) dengan meninggalkan 1 tanaman yang pertumbuhannya paling baik. Penyulaman dilakukan bersamaan dengan waktu penjarangan. Pemupukan dilakukan 1 mst untuk pupuk urea, TSP, dan $\mathrm{KCl}$ masing-masing pada dosis $100 \mathrm{~kg} / \mathrm{ha}$ dan pupuk urea susulan diberikan 4 mst dengan dosis $100 \mathrm{~kg} / \mathrm{ha}$. Pengendalian gulma dilakukan dengan cara penyiangan bersamaan dengan waktupembumbunan yang dilakukan 2 kali, yaitu pada saat tanaman berumur 3 mst dan 6 mst. Pengendalian hama dilakukan menggunakan insektisida berbahan aktif metomil $25 \%$ dengan dosis $1,5 \mathrm{~g} / \mathrm{L}$ dan untuk pengendalian penyakit menggunakan fungsida berbahan aktif mankozeb.

Panen dilakukan secara manual dan dilaksanakan saat tanaman sudah menunjukkan kriteria panen, yaitu berumur 60-80 hst yang ditandai dengan penampakan rambut luar mengering berwarna coklat kehitaman, tongkol keras bila digenggam, dan warna biji menguning.Variabel yang diamati meliputi tinggi tanaman $(\mathrm{cm})$, diameter batang (mm), umur muncul bunga jantan (hst), umur muncul bunga betina (hst), tinggi tongkol $(\mathrm{cm})$, panjang tongkol berkelobot $(\mathrm{cm})$, panjang tongkol tanpa kelobot $(\mathrm{cm})$, diameter tongkol berkelobot ( $\mathrm{mm})$, diameter tongkol tanpa kelobot (mm), bobot tongkol berkelobot (g), bobot tongkol tanpa kelobot (g), jumlah baris biji per tongkol, jumlah biji per baris, bobot tongkol per petak (kg), dan total padatan terlarut ( ${ }^{\circ}$ brix). Data hasil pengamatan dianalisis secara 
statistik dengan uji analisis varian. Jika terdapat perbedaan nyata antar perlakuan dilanjutkan dengan uji Duncan's Multiple Range Test (DMRT) pada $p=0,05$.

\section{HASIL DAN PEMBAHASAN}

\section{Karakter pertumbuhan tanaman}

Hasil analisis varian (Tabel 2) menunjukkan bahwa pertumbuhan tanaman (tinggi tanaman, tinggi tongkol, diameter batang, umur berbunga jantan, dan umur berbunga betina tidak berbeda nyata antar genotipe. Pada Tabel 3 disajikan perbandingan karakter pertumbuhan tanaman antar genotipe. Postur tanaman yang secara keseluruhan termasuk kedalam kategori sedang dan diameter batang termasuk kategori besar, maka tanaman dari genotipe yang dievaluasi tidak mudah mengalami kerebahan, termasuk didaerah yang memiliki tiupan angin kencang, dan mudah dalam pemeliharaan (Widowati et al., 2016).

Tabel 1. Hasil evaluasi karakter pertumbuhan dan hasil 13 jagung manis hibrida

\begin{tabular}{lrrrr}
\hline \multicolumn{1}{c}{ Sumber keragaman } & Maximum & Minimum & Rata-rata & $\begin{array}{c}\text { Koefisien } \\
\text { Keragaman (\%) }\end{array}$ \\
\hline Tinggi tanaman (cm) & 220,90 & 165,40 & 188,43 & 8,86 \\
Tinggi letak tongkol (cm) & 132,30 & 63,00 & 100,59 & 12,45 \\
Diameter batang (mm) & 23,11 & 11,24 & 17,56 & 10,15 \\
Umur berbunga jantan (HST) & 52,00 & 43,00 & 45,21 & 4,65 \\
Umur berbunga betina (HST) & 58,00 & 45,00 & 47,77 & 5,44 \\
Panjang tongkol berkelobot (cm) & 35,80 & 22,20 & 28,77 & 6,81 \\
Diameter tongkol berkelobot (mm) & 57,47 & 41,46 & 51,93 & 5,57 \\
Bobot tongkol berkelobot (g) & 390,20 & 189,90 & 284,77 & 12,33 \\
Panjang tongkol tanpa kelobot (cm) & 20,55 & 15,50 & 18,53 & 4,51 \\
Diameter tongkol tanpa kelobot & & & & \\
(mm) & 48,99 & 34,88 & 43,82 & 5,23 \\
Bobot tongkol tanpa kelobot (g) & 282,10 & 142,20 & 193,46 & 9,33 \\
Bobot tongkol per petak (kg) & 20,46 & 6,67 & 11,42 & 20,04 \\
Jumlah baris & 16,10 & 11,50 & 13,70 & 5,46 \\
Jumlah biji & 41,30 & 21,50 & 34,72 & 9,44 \\
Total padatan terlarut $\left({ }^{\circ}\right.$ brix) & 15,00 & 11,00 & 13,54 & 7,51 \\
\hline
\end{tabular}

Tabel 2. Uji keragaman karakter pertumbuhan 13 jagung manis hibrida

\begin{tabular}{lccc}
\hline \multicolumn{1}{c}{ Variabel } & F-hitung & F-tabel $5 \%$ & F-tabel 1\% \\
\hline Tinggi tanaman $(\mathrm{cm})$ & $0,83 \mathrm{~ns}$ & 2,18 & 3,03 \\
Tinggi tongkol $(\mathrm{cm})$ & $0,81 \mathrm{~ns}$ & 2,18 & 3,03 \\
Diameter batang (mm) & $1,75 \mathrm{~ns}$ & 2,18 & 3,03 \\
Umur bunga jantan (HST) & $1,65 \mathrm{~ns}$ & 2,18 & 3,03 \\
Umur bunga betina (HST) & $1,44 \mathrm{~ns}$ & 2,18 & 3,03 \\
\hline
\end{tabular}

Keterangan: $\mathrm{ns}=$ tidak berbeda nyata 
Tabel 3. Karakter pertumbuhan 13 jagung manis hibrida

\begin{tabular}{lccccc}
\hline \multicolumn{1}{c}{ Genotipe } & $\begin{array}{c}\text { Tinggi } \\
\text { Tanaman } \\
(\mathrm{cm})\end{array}$ & $\begin{array}{c}\text { Tinggi } \\
\text { Tongkol } \\
(\mathrm{cm})\end{array}$ & $\begin{array}{c}\text { Diameter } \\
\text { Batang } \\
(\mathrm{mm})\end{array}$ & $\begin{array}{c}\text { Umur Mncul } \\
\text { Bunga Jantan } \\
(\text { HST })\end{array}$ & $\begin{array}{c}\text { Umur Muncul } \\
\text { Bunga Betina } \\
(\mathrm{HST})\end{array}$ \\
\hline Caps2 x Caps15 & 189,53 & 101,00 & 17,73 & 43,00 & 45,33 \\
Caps3 x Caps5 & 189,57 & 103,13 & 16,82 & 44,67 & 47,00 \\
Caps3 x Caps23 & 192,37 & 105,37 & 18,58 & 44,33 & 46,67 \\
Caps5 x Caps17b & 187,63 & 102,97 & 17,18 & 46,00 & 48,33 \\
Caps5 x Caps22 & 194,03 & 112,77 & 17,63 & 45,33 & 47,67 \\
Caps15 x Caps22 & 172,30 & 96,57 & 20,37 & 44,00 & 47,00 \\
Caps15 x Caps17a & 199,90 & 105,80 & 17,94 & 43,67 & 46,00 \\
Caps17b x Caps23 & 199,90 & 106,33 & 19,15 & 43,33 & 46,00 \\
Caps17b x Caps22 & 189,10 & 99,27 & 18,32 & 45,33 & 47,33 \\
Caps17a x Caps22 & 184,27 & 93,30 & 16,11 & 47,33 & 50,67 \\
Caps17a x Caps17b & 178,00 & 96,33 & 16,89 & 47,33 & 50,00 \\
Caps22 x Caps23 & 196,97 & 97,03 & 15,27 & 45,67 & 48,00 \\
Paragon & 176,07 & 87,83 & 16,32 & 47,67 & 51,00 \\
\hline
\end{tabular}

Tabel 4. Uji keragaman hasil dan komponen hasil 13 jagung manis hibrida

\begin{tabular}{llcc}
\hline \multicolumn{1}{c}{ Variabel } & F-hitung & F-tabel 5\% & F-tabel 1\% \\
\hline Panjang tongkol berkelobot $(\mathrm{cm})$ & $3,23^{* *}$ & 2,18 & 3,03 \\
Diameter tongkol berkelobot $(\mathrm{mm})$ & $2,17 \mathrm{~ns}$ & 2,18 & 3,03 \\
Bobot tongkol berkelobot $(\mathrm{g})$ & $1,18 \mathrm{~ns}$ & 2,18 & 3,03 \\
Panjang tongkol tanpa kelobot $(\mathrm{cm})$ & $3,01^{*}$ & 2,18 & 3,03 \\
Diameter tongkol tanpa kelobot $(\mathrm{mm})$ & $3,27^{* *}$ & 2,18 & 3,03 \\
Bobot tongkol tanpa kelobot $(\mathrm{g})$ & $2,62^{*}$ & 2,18 & 3,03 \\
Bobot per petak $(\mathrm{kg})$ & $1,34 \mathrm{~ns}$ & 2,18 & 3,03 \\
\hline
\end{tabular}

Keterangan: $\mathrm{ns}=$ berbeda tidak nyata, $*$ = berbeda nyata $\left(\mathrm{F}_{0,05}\right), * *=$ berbeda sangat nyata $\left(\mathrm{F}_{0,01}\right)$.

\section{Komponen Hasil dan Hasil Tanaman}

Hasil analisis varian (Tabel 4) menunjukkan nilai keragaman yang nyata antar genotipe pada komponen hasil kecuali diameter tongkol berkelobot, bobot tongkol berkelobot, dan hasil per petak. Ukuran tongkol baik berkelobot maupun tanpa kelobot mempunyai keterkaitan erat dengan hasil tanaman jagung manis (Chozin et al., 2017). Selain itu, harga jagung manis juga sangat ditentukan oleh ukuran tongkol. Dengan demikian,semakin besar ukuran tongkol berarti semakin besar juga hasil dan harga yang diharapkan per satuan luas.

Pada Tabel 5 disajikan komponen hasil dan hasil jagung manis per petak. Oleh karena Paragon yang digunakan sebagai varietas pembanding, maka penampilan hibrida yang dievaluasi idealnya lebih baik dibandingkan Paragon. Paragon merupakan hibrida F1 yang telah dilepas secara komersial dan memiliki produktivitas relatif tinggi. Dalam penelitian ini, terdapat empat persilangan (Caps3 x Caps23, Caps17b x 
Tabel 5. Hasil dan komponen hasil 13 jagung manis hibrida

\begin{tabular}{|c|c|c|c|c|c|c|c|c|c|c|c|}
\hline Genotipe & $\begin{array}{l}\text { Panjang } \\
\text { berkelo }\end{array}$ & $\begin{array}{l}\text { tongkol } \\
\text { ot }(\mathrm{cm})\end{array}$ & $\begin{array}{c}\text { Diameter } \\
\text { tongkol } \\
\text { berkelobot }(\mathrm{mm})\end{array}$ & $\begin{array}{l}\text { Bobot tongkol } \\
\text { berkelobot }(\mathrm{g})\end{array}$ & $\begin{array}{r}\text { Panjang } \\
\text { tanpa } \\
\text { (c }\end{array}$ & $\begin{array}{l}\text { ongkol } \\
\text { lobot }\end{array}$ & $\begin{array}{r}\text { Dian } \\
\text { tongko } \\
\text { kelobo }\end{array}$ & $\begin{array}{l}\text { eter } \\
\text { tanpa } \\
(\mathrm{mm})\end{array}$ & $\begin{array}{r}\text { Bobot to } \\
\text { tanpa ke } \\
(\mathrm{g})\end{array}$ & & $\begin{array}{l}\text { Bobot per } \\
\text { petak }(\mathrm{kg})\end{array}$ \\
\hline Caps 2 x Caps 15 & 26,73 & $\mathrm{~cd}$ & 52,87 & 285,53 & 18,70 & $a-d$ & 45,07 & $\mathrm{ab}$ & 197,27 & $a b$ & 13,26 \\
\hline Caps 3 x Caps 5 & 25,83 & $\mathrm{~d}$ & 53,33 & 288,57 & 17,26 & $\mathrm{~d}$ & 46,30 & $\mathrm{a}$ & 216,90 & $\mathrm{a}$ & 13,58 \\
\hline Caps 3 x Caps 23 & 28,27 & bcd & 52,02 & 280,20 & 18,80 & $a-d$ & 44,29 & $a b$ & 204,93 & $a b$ & 11,54 \\
\hline Caps 5 x Caps 17b & 28,93 & $a-d$ & 50,39 & 256,70 & 18,86 & abcd & 41,05 & bc & 171,00 & bc & 12,02 \\
\hline Caps 5 x Caps 22 & 30,78 & $\mathrm{ab}$ & 52,37 & 300,73 & 19,01 & $a b c$ & 43,98 & $a b$ & 201,73 & $a b$ & 11,22 \\
\hline Caps 15 x Caps 22 & 32,43 & $\mathrm{a}$ & 52,32 & 322,03 & 19,53 & $\mathrm{a}$ & 43,74 & $a b$ & 188,30 & $a b$ & 10,87 \\
\hline Caps 15 x Caps $17 \mathrm{a}$ & 30,65 & $a b$ & 52,77 & 298,70 & 19,21 & $a b$ & 42,79 & $a b$ & 188,33 & $a b$ & 12,56 \\
\hline Caps 17b x Caps 23 & 30,97 & $a b$ & 53,52 & 307,10 & 17,76 & bcd & 45,37 & $a b$ & 212,77 & $\mathrm{a}$ & 14,50 \\
\hline Caps $17 b$ x Caps 22 & 27,82 & bcd & 54,57 & 300,73 & 18,81 & $a-d$ & 43,77 & $a b$ & 200,27 & $a b$ & 10,65 \\
\hline Caps 17a x Caps 22 & 29,88 & $\mathrm{abc}$ & 46,93 & 243,97 & 20,01 & $\mathrm{a}$ & 37,86 & $\mathrm{c}$ & 154,10 & $\mathrm{c}$ & 9,46 \\
\hline Caps $17 \mathrm{a} \times$ Caps $17 \mathrm{~b}$ & 26,70 & $\mathrm{~cd}$ & 54,30 & 287,07 & 17,50 & $\mathrm{~cd}$ & 46,53 & $\mathrm{a}$ & 196,13 & $a b$ & 9,15 \\
\hline Caps 22 x Caps 23 & 28,30 & bcd & 52,79 & 263,80 & 17,76 & bcd & 46,22 & $\mathrm{a}$ & 184,10 & abc & 10,03 \\
\hline Paragon & 26,73 & $\mathrm{~cd}$ & 46,88 & 266,90 & 17,83 & bcd & 42,73 & $a b$ & 199,10 & $a b$ & 9,56 \\
\hline
\end{tabular}

Keterangan : nilai yang diikuti oleh huruf yang berbeda pada kolom yang sama menunjukan berbeda nyata pada uji DMRT $p=0,05$. 
Caps23, Caps17b x Caps22, dan Caps22 x Caps23) yang memiliki ukuran tongkol berkelobot lebih panjang dibandingkan Paragon $(>26,7 \mathrm{~cm})$. Demikian juga, terdapat dua persilangan (Caps17b $\mathrm{x}$ Caps23 dan Caps17a x Caps17b) yang memiliki ukuran panjang tongkol tanpa kelobot yang lebih panjang dibandingkan Paragon (>17,8 cm). Dalam deskripsi varietas, Paragon memiliki kisaran panjang tongkol antara 16,18 dan 20,17 cm. Pada penelitian Subardja et al. (2017), Paragon yang dipupuk dengan $375 \mathrm{~kg} /$ ha urea dan 2 ton/ha kompos hanya menghasilkan tongkol berkelobot yang memiliki panjang $21,0 \mathrm{~cm}$. Mahdiannoor (2014) juga melaporkan bahwa Paragon yang diberi pupuk hayati dengan dosis 12 1/ha menghasilkan panjang tongkol tanpa kelobot hanya $20,13 \mathrm{~cm}$.

Diameter tongkol berkelobot tidak menunjukkan keragaman yang nyata antar genotipe.Diameter tongkol tanpa kelobot umumnya memiliki nilai yang setara kecuali satu persilangan (Caps17a xCaps22) yang memiliki nilai lebih kecil dibandingkan Paragon (>42,73 $\mathrm{mm})$. Dalam penelitian Syofia et al. (2014), Paragon yangdiberi pupuk Santamicro menghasilkan diameter tongkol tanpa kelobot sebesar 49,5 mm.

Bobot tongkol merupakan cerminan dari diamater tongkol, panjang tongkol, dan jumlah baris biji per tongkol (Boer, 2011). Secara statistik, bobot tongkol berkelobot tidak menunjukkan keragaman yang nyata antar gonotipe termasuk Paragon. Namun, bobot tongkol tanpa kelobot menunjukkan keragaman yang nyata dari seluruh persilangan, kecuali Caps17a x Caps22 yangmemiliki rata-rata lebih sedikit dibandingkan Paragon. Hasil penelitian Rambe (2014) menunjukkan bahwa Paragon yang dipupuk NPK dengan dosis $300 \mathrm{~kg} /$ ha dan pupuk organik cair $120 \mathrm{~g} /$ plot menghasilkan bobot tongkol 181,32 g.

\section{Kualitas Hasil Jagung Manis}

Indikator utama kualitas jagung manis ditentukan dari jumlah baris biji dan kandungan gula atau tingkat kemanisannya. Pada Tabel 6 disajikan hasil analisis keragaman untuk kualitas hasil. Dari tiga sifat kualitas yang dievaluasi, dua diantaranya (jumlah baris dalam tongkol dan total padatan terlarut) menunjukkan keragaman yang nyata antar genotipe.

Jumlah baris biji merupakan penentu kualitas jagung manis yang penting. Hasil penelitian Seyedzavar et al. (2015) menunjukkan, jumlah baris biji per tongkol berkaitan erat dengan diameter tongkol. Pada umumnya tongkol jagung manis memiliki 12 hingga 16 baris biji (Surtinah, 2008). Dalam deskripsi varietas, Paragon memiliki jumlah baris biji antara 14 dan 16 . Dari 12 genotipe yang dievaluasi, empat persilangan diantaranya (Caps3 x Caps23, Caps15 x Caps22, Caps17b x Caps23, dan Caps17b x Caps22) memiliki jumlah baris 
Tabel 6. Nilai F hitung kualitas hasil tanaman

\begin{tabular}{llcc}
\hline \multicolumn{1}{c}{ Variabel } & F-hitung & F-tabel 5\% & F-tabel 1\% \\
\hline Jumlah biji per baris & $1,46 \mathrm{~ns}$ & 2,18 & 3,03 \\
Jumlah baris & $2,57^{*}$ & 2,18 & 3,03 \\
Total padatan terlarut $\left({ }^{\circ}\right.$ brix $)$ & $2,18^{*}$ & 2,18 & 3,03 \\
\hline
\end{tabular}

Keterangan: $\mathrm{ns}=$ berbeda tidak nyata, $*=$ berbeda nyata $\left(\mathrm{F}_{0,05}\right),{ }^{*}=$ berbeda sangat nyata $\left(\mathrm{F}_{0,01}\right)$.

Tabel 7. Rata-rata kualitas hasil tanaman

\begin{tabular}{|c|c|c|c|c|}
\hline Genotipe & $\begin{array}{c}\text { Jumlah baris dalam } \\
\text { tongkol }\end{array}$ & $\begin{array}{c}\text { Jumlah biji per } \\
\text { baris }\end{array}$ & $\begin{array}{l}\text { Total pad } \\
\text { terlarut }\left(^{\circ}\right.\end{array}$ & $\begin{array}{l}\text { datan } \\
\text { obrix) }\end{array}$ \\
\hline Caps 2 x Caps15 & $13,06 \mathrm{~cd}$ & 37,50 & 14,33 & $\mathrm{a}$ \\
\hline Caps3 x Caps5 & 13,66 a-d & 34,37 & 13,33 & $a b c$ \\
\hline Caps 3 x Caps 23 & 14,70 & 36,37 & 14,00 & $\mathrm{a}$ \\
\hline Caps5 x Caps17b & 13,43 abcd & 36,00 & 14,00 & $\mathrm{a}$ \\
\hline Caps5 x Caps22 & $13,13 \mathrm{~cd}$ & 36,07 & 12,00 & $\mathrm{bc}$ \\
\hline Caps 15 x Caps 22 & $14,06 \quad a b c$ & 36,73 & 11,66 & $\mathrm{c}$ \\
\hline Caps 15 x Caps $17 \mathrm{a}$ & 14,86 & 32,37 & 13,66 & $\mathrm{ab}$ \\
\hline Caps17b x Caps 23 & 14,50 & 36,87 & 14,00 & $\mathrm{a}$ \\
\hline Caps $17 b$ x Caps 22 & 13,90 & 36,20 & 14,33 & $\mathrm{a}$ \\
\hline Caps17a x Caps22 & 13,70 & 34,00 & 14,33 & $\mathrm{a}$ \\
\hline Caps17a x Caps17b & 13,36 & 33,00 & 13,00 & $a b c$ \\
\hline Caps 22 x Caps 23 & 13,13 & 30,77 & 14,00 & $\mathrm{a}$ \\
\hline Paragon & $12,53 \mathrm{~d}$ & 31,07 & 13,33 & $a b c$ \\
\hline
\end{tabular}

Keterangan : nilai yang diikuti oleh huruf yang berbeda pada kolom yang sama menunjukan berbeda nyata pada uji DMRT $p=0,05$.

yang lebih banyak dibandingkan Paragon.

Demikian juga dengan tingkat kemanisan setara dengan Paragon yang memiliki total padatan terlarut $13,3^{\circ}$ brix. Dalam deskripsi varietas, Paragon memiliki kisaran total padatan terlarut antara 11,47 dan $11,77^{\circ}$ brix (Tabel 7). Sementara total padatan terlarut dari Paragon dalam penelititan Surtinah (2008) memiliki kisaran antara $8,44 \square$ brix dan 15,78 $\square$ brix. Nainggolan dan Hapsoh (2017) melaporkan bahwa Paragon yang dipupuk NPK dengan dosis 150 hingga 300 $\mathrm{kg}$ /ha menghasilkan tongkol dengan jumlah baris mencapai 12,95 baris biji.

\section{KESIMPULAN}

Secara umum genotipe jagung manis hibrida yang dievaluasi menunjukkan penampilan pertumbuhan dan hasil setara dengan Paragon yang digunakan sebagai varietas pembanding. Pengecualian dijumpai pada Caps15 x Caps22 yang mempunyai ukuran tongkol berkelobot dan tanpa kelobot lebih panjang dan pada Caps 15x Caps17a yang memiliki jumlah baris lebih banyak dibandingkan Paragon.

\section{DAFTAR PUSTAKA}

Boer, D. 2011. Analisis variabilitas genetik dan koefisien lintas berbagai karakter agronomidan fisiologi terhadap hasil 
biji dari keragaman genetik 54 asesi jagung asalIndonesia Timur. Jurnal Agroteknos, 1(1): 35 - 43.

Chozin, M., S. Sudjatmiko, N. Setyowati, Fahrurrozi dan Z. Muktamar. 2017. Daya gabung karakteristik tongkol dari galur-galur inbrida jagung manis pada sistem budidaya organik. Jurnal Hortikultura Indonesia, 8 (1): 34 58.

Dewani, M. 2004. Pengaruh pemberian dosis pupuk $\mathrm{N}, \mathrm{P}$ dan $\mathrm{K}$ terhadap pertumbuhan dan hasil tanaman jagung manis. Journal of Habitat, 15(1): $31-44$.

Dewanto, F. G., J. J. M. R. Londok, R. A. V. Tuturoong dan W. B. Kaunang. 2013. Pengaruh pemupukan anorganik dan organik terhadap produksi tanaman jagung sebagai sumber pakan. Jurnal Zootek, 32(5): $1-8$.

Firnia, D. dan A. A. Fatmawaty. 2009. Pertumbuhan dan hasil tanaman jagung manis (Zea mays saccharataSturt) pada berbagai dosis pupuk organik dan intensitas pengolahan tanah ultisolsBanten. Jurnal Agroekoteknologi, 1(2): 16 26.

Mahdiannoor. 2014. Pertumbuhan dan hasil tanaman jagung manis (Zea maysL. varsaccharata) dengan pemberian pupuk hayati pada lahan rawa lebak.Ziraa'ah, 39(3): 105 - 113.

Martani, E., B.H. Sunarminto, S. Margino dan S. Handayani. 2000. Herbisida paraquat dilahan gambut: pengaruhnya terhadap tanah dan pertumbuhan jagung.Jurnal Manusia dan Lingkungan, 7(2): 35 - 44.

Nainggolan, G. dan Hapsoh. 2017. Respons tanaman jagung manis (Zea mays saccharata Sturt) yang diberi pupuk guano dengan NPK di lahan gambut. Jurnal Online Mahasiswa Fakultas
Pertanian Universitas Riau, 4 (2): 1 15.

Prahastuti, S.W. 2005. Perubahan beberapa sifat kimia dan serapan $P$ jagung akibat pemberian bahan organik dan batuan fosfat alam pada ultisol Jasinga. Agroland Jurnal Ilmu-ilmu Pertanian, 12(1): 68 - 74 .

Rambe, R. D. H. 2014. Pengaruh pemberian pupuk organik dan pupuk anorganik terhadap pertumbuhan dan produksi jagung manis (Zea mays saccharata L.). Wahana Inovasi, 3(2): 436 - 443.

Rubatzky, V. E., and M. Yamaguchi. 1997. World Vegetables: Principles, Production, and Nutritive Values, 2nd ed. Chapman and Hall, New York.

Seyedzavar, J., M. Norouzi, and S. Aharizad. 2015. Relationships of morphological characters and yield components in corn hybrids under waterdeficit stress. Biological ForumAn International Journal, 7(1): 1512 $-1519$.

Soegito dan Adie. 1993. Teknik Bercocok Tanam Jagung. Penerbit Kanisius, Yogyakarta.

Subagyo, H., N. Suharto dan A.B. Siswanto. 2004. Tanah-tanah Pertanian di Indonesia.Rineka Cipta, Jakarta.

Subardja, V., Muharam dan S. Nugraha. 2017. Karakteristik pertumbuhan dan hasil jagung manis dilahan marginal dengan dosis pemupukan $\mathrm{N}$ yang berbeda. Jurnal Agrotek Indonesia, 2(1): $7-12$.

Surtinah. 2008. Waktu panen yang tepat menentukan kandungan gula biji jagung manis (Zea mays saccharata). Jurnal Ilmiah Pertanian, 4(2): 1 - 4.

Syofia, I., A. Munar dan M. H. D. Sofyan. 2014. Pengaruh pupuk organik cair terhadap pertumbuhan dan hasil dua varietas tanaman jagung manis (Zea mays saccharata Sturt).Jurnal Agrium, 18(3): 208 - 218. 
p-ISSN: 1410-0029; e-ISSN2549-6786

Agrin Vol. 23, No. 2, Oktober 2019

Szymanek, M., B. Dobrzański, I. Niedziółka, and R. Rybczyński. 2006.

Sweet Corn: Harvest and Technology Physical Properties and Quality. Bohdan Dobrzański Institute of Agrophysics, Polish Academy of Widowati, A., Ainurrasjid, dan A. N. Sugiharto. 2016. Karakterisasi beberapa galur inbrida jagung manis (Zea mays L. Saccharata). Jurnal Produksi Tanaman, 4(1): 1 - 7 .

Sciences, Lublin. 